\title{
Determinant Factors of Founding-Family Firms' Performance in Indonesia
}

\author{
Alex Johanes Simamora \\ Independent Researcher \\ *corresponding author e-mail: alexjohanessimamora@gmail.com
}

\begin{tabular}{ll}
\hline Article Info & Abstract \\
& This research aims to examine the factors that moderate the effect of \\
Keywords: & founding-family firms on performance. Moderating variables include \\
Founding-Family Firms; & firm reputation, risk-taking behavior, agency costs of managers- \\
Firms' Performance; & shareholders, and agency costs of majority-minority shareholders. \\
Firm Reputation; & Firms' performance includes accounting-based and market-based \\
Risk-Taking Behavior; & performance. This research uses 412 manufacturing firm-years listed \\
Agency Costs & on the Indonesian Stock Exchange as the research sample. The \\
& hypotheses test uses a random-effect regression as the main test and a \\
& common-effect regression test as an alternative test. Based on data \\
analysis, firm reputation, risk-taking behavior, agency costs of & mangers-shareholders, and agency costs of majority-minority \\
& shareholders moderates the effect of the founding family on \\
& performance. It indicates that founding-family firms can achieve \\
higher performance if they promote a higher firm reputation, lower \\
risk-taking behavior, and lower agency costs. This research fills the \\
previous findings gap of performance in the founding-family firms. \\
This research captures when founding-family firms can improve \\
performance or experience performance reduction. To the best of the \\
author's knowledge, this research is also the first research that \\
provides a comprehensive picture of determinant factors of founding- \\
family firms' in Indonesia.
\end{tabular}

\section{Introduction}

\section{Background}

Based on a survey in 2018, founding-family firms achieve sales growth of 42 to $65 \%$ in Indonesia and 64 to $69 \%$ at the global level in the last two years (PricewaterhouseCoopers, 2019). Both in Indonesia and global level, founding-family firms also have a projection to increase their sales aggressively (PricewaterhouseCoopers, 2019) and put the main concern in financial performance and profitability improvement (Deloitte, 2019) in the next five years. The survey result shows that founding-family firms have superior performance and keep to maintain it the future. It is supported by Martin-Reyna and Duran-Encalada (2015), Zattoni et al. (2015), and Ntoung et al. (2017) who find that founding-family firms have better performance than non-family ones.

Some factors support founding-family firms to achieve better performance. First, other family members are involved in the firm's board and management. Since founding-family firms are run based on family value (PricewaterhouseCoopers, 2019), it leads to interest alignment between 
shareholders and management. In this case, there is a lower agency conflict between foundingfamily shareholders and managers since they hold the same family value. Second, one of the most important family values is socioemotional wealth (Kalm \& Gomez-Mejia, 2016). Socioemotional wealth leads founding-family to run the business based on family interest, such as reputation. Reputation development becomes one of the founding-family firms' key strategies to build business relationships with suppliers, creditors, or customers (Anderson \& Reeb, 2003). Third, socioemotional wealth also brings founding-family firms to avoid risk. Founding-family has the interest to maintain their accumulated wealth and make a legacy to the next generation by reducing future uncertainty and avoiding risk (Zahra, 2018).

On the other hand, Bambang and Hermawan (2012), Juniarti (2015), and Harjito et al. (2021) find that founding-family firms have lower performance than non-family ones. It explains that there are factors that lead founding-family fails to achieve better performance. First, foundingfamily firms are sensitive to risk and bad reputations (Vieira, 2014). Since socioemotional wealth leads founding-family firms to maintain reputation and avoid risk, a risky strategy and bad reputation bring lower performance. Second, family value is not aligned with non-family parties, such as minority shareholders. Damayanti et al. (2018) explain that conflict of minority-majority shareholders happens in the founding-family firms, especially firms with ultimate ownership by family. In this case, higher conflict of minority-majority shareholders caused by entrenchment effect that leads to abuse of power (Sanjaya, 2016). Abuse of power by majority shareholders of founding-family contributes to the ineffectiveness of performance improvement strategy, such as avoiding the risk-taking that can lead to innovation, or enhance the collusive system in the firms' management structure.

Inconsistent of previous findings come from the gap of previous studies that do not involve the factors that determine founding-family firms' performance. This research examines the role of determinant factors of founding-family firms to explain the ability of founding-family firms to improve performance. The determinant factors include firm reputation, firm risk-taking, conflict of manager-shareholder, and conflict of majority-minority shareholders.

Firm reputation refers to the perception of customers, investors, employees, and the general public on the firm image (Lee \& Roh, 2012). Reputation is one of the important intangible assets for firms to differentiate them from other firms. Since founding-family firms have a value of socioemotional wealth that leads them to build and maintain the family name, reputation is used by founding-family firms to create good branding and image to make a profitable relationship with all stakeholders. Since reputation is also a competitive advantage to increase performance (Lee \& Roh, 2012), founding-family firms with higher reputations can achieve better performance.

Risk-taking refers to firms' behavior to take a risky strategy. Although risk-taking can lead firms to the innovation of new technology and market (McKinley et al., 2014), it also can bring firms to the uncertainty that can lead to survival problems and potential of default (Tsai \& Luan, 2016). Socioemotional wealth suggests that founding-family firms avoid risk and uncertainty to ensure the firms' survival since the firms will be inherited to the next family generation. In this case, founding-family firms increase performance by taking a lower-risk business strategy.

Agency conflict is also a problem for firms to improve performance since higher conflict leads to higher costs (Jensen \& Meckling, 1976). There are two types of conflict which are conflicts of manager-shareholders and majority-minority shareholders. Founding-family firms have lower manager-shareholders conflict but, on the other hand, also have higher majority-minority shareholders conflict. Both conflicts give a reduction of performance results for founding-family firms. In this case, the gap can be solved if both agency conflicts are included in the relationship between founding-family firms and performance. By having lower agency conflicts, both 
manager-shareholders, and majority-minority shareholders, firms bear less agency cost and have better performance.

This research gives some contributions. First, this research fills the previous findings gap of performance in the founding-family firms (e.g.(Bambang \& Hermawan, 2012; Harjito et al., 2021; Juniarti, 2015; Martin-Reyna \& Duran-Encalada, 2015; Ntoung et al., 2017; Zattoni et al., 2015). By involving founding-family firms' factors that can determine firms' performance, this research captures when founding-family firms can improve performance or experience performance reduction. Second, to the best of the author's knowledge, this research is the first research that provides a comprehensive picture of determinant factors of founding-family firms' in Indonesia. In an emerging market such as the Indonesian market where the family business gives a major contribution to the national economy (Susanto et al., 2007), it is important to examine the factors to ensure when founding-family family firms can give optimal performance.

\section{Hypotheses Development}

\section{Reputation, Founding-Family Firms, and Performance}

Founding-family firms hold a family value of socioemotional wealth (Kalm \& Gomez-Mejia, 2016). One of the socioemotional wealth objectives is to maintain the family name and social status by increasing the firm reputation. Founding-family firms' reputation is built to make longterm benefits (Sageder et al., 2018) to prepare the firms that can be passed down to the next generation (Alves \& Gama, 2020; Andres, 2008; Tabor et al., 2018). Some studies find that founding-family firms maintain their reputation by building the trust and loyalty to make longterm relationships with customers (Craig et al., 2008; Levenburg, 2006), engaging in environmental and social responsibilities (Berrone et al., 2010; Dyer \& Whetten, 2006), and avoiding employees' dismissal and job cuts (Block, 2010).

Firm reputation is one of the most important intangible assets to improve firm business. It is a competitive advantage had by firms to maintain business and economic relationships with stakeholders. For employees, firm reputation is one of the factors that attract them to keep working in the firms, especially in the founding family firms that avoid employees' dismissal and job cuts. Firms can keep productive employees to stay and improve firms' performance. Firm reputation is also a good signal for investors and shareholders so the market will give positive responses (Cole, 2013). Reputation also helps firms to reduce the cost of capital since reputable firms provide higher quality information with lower asymmetry, improve risk sharing, and increase investor and creditor recognition (Cao et al., 2015). Reputable firms will use their reputation as a brand for customers that can maintain loyal customers or create a new segment of customers (Lee \& Roh, 2012). The ability to maintain customers leads firms to have higher revenues. In the context of founding-family firms' reputation, factors of productive employees, lower cost of equity, and higher revenues bring firms to improve performance. Lee and Roh (2012) and Sánchez and de Vega (2018) find that reputation has a positive effect on firms' performance.

H1: Firm reputation moderates the effect of founding-family firms on performance

\section{Risk-Taking Behavior, Founding-Family Firms, and Performance}

Founding-family firms tend to be risk-averse since they invest their whole human and financial capital into the firms (Jiang et al., 2015). Socioemotional wealth also leads founding-family firms to take less risky strategies. Founding-family needs to ensure that firms are reputable to pass down to the next generation by engaging in less uncertain conditions and potential of bankruptcy. Although risk-taking behavior brings an opportunity for innovation (McKinley et al., 2014), 
founding-family firms do not take the innovation opportunity and focus on reputation development (Deloitte, 2019; PricewaterhouseCoopers, 2019). Jiang et al. (2015) find that founding-family firms have a negative effect on risk-taking behavior. Gottardo and Moisello (2017) also find that founding-family firms reduce risk-taking behavior and financial distress.

Based on the threat-rigidity hypothesis, risk-taking behavior leads firms to face the threat of loss and higher uncertainty costs (Staw et al., 1981). It will disturb firms' survival system, lead to revenue reduction, and experience the potential of losses (Miller \& Bromiley, 1990). In this case, founding-family firms should achieve optimal performance by avoiding a higher risk business strategy since risk-averse behavior can improve performance, at the same time, also can fulfill the family interests of reputation. Chattopadhyay et al. (2001) find that risk-taking behavior increases the potential of losses. Miller and Bromiley (1990) and Olaniran et al. (2016) also find that risktaking behavior decreases firms' performance.

H2: Risk-taking behavior moderates the effect of founding-family firms on performance

\section{Agency Costs of Managers-Shareholders, Founding-Family Firms, and Performance}

As shareholders, the founding family has the role to monitor and control managers' behavior. It can reduce agency conflict of managers-shareholders. The condition where both manager and shareholder are founding-family also leads to interest alignment since they have the same family value. Lower agency conflict of managers-shareholders leads firms to bear fewer agency costs. Zhang and Cao (2016) find that founding-family involvement in management reduces agency costs of managers-shareholders.

Higher agency conflict of managers-shareholders brings higher costs and leads to performance reduction. Agency costs of managers-shareholders include costs of monitoring, costs of bonding, and costs of residual losses (Jensen \& Meckling, 1976). Costs of monitoring refer to the costs paid by firms to monitor managers' behavior, such as auditor costs. Costs of bonding refer to the costs paid by firms to engage managers with shareholders' interests, such as managers' compensation. Costs of residual losses refer to the costs where managers utilize firms' facilities for managers' private interests but not for firms' needs. In this case, founding-family firms can improve performance because they have lower agency costs of managers-shareholders. Jabbary et al. (2013) and Hoang et al. (2019) find that agency costs managers-shareholders reduce firms' performance.

H3: Agency costs of managers-shareholders moderate the effect of founding-family firms on performance

This research uses four proxies of agency costs of managers-shareholders which are operating expenses ratio, free cash flow, assets growth, and collateral assets. Operating expenses refers to the expenses that are consumed by managers, including direct agency costs such as compensation, facilities, and auditor fee (Ang et al., 2000; Armanto et al., 2014). Higher agency costs of managers-shareholders reflect higher managerial discretionary for consumption and utilization in operating expenses (Chamidah \& Asandimitra, 2017; Singh \& Davidson III, 2003). In the context of founding-family firms, the firms can improve performance they have a lower operating expenses ratio. Muriithi (2017) and Faisal et al. (2021) find that lower operating expenses lead to higher firms' performance.

H3a: Operating expenses ratio moderates the effect of founding-family firms on performance

Free cash flow refers to excessive operating cash flow after paying long-term investments and dividends (Lin \& Lin, 2013). Based on the free cash flow hypothesis, when managers have more free cash flow after investing in all positive returns projects, managers get an opportunity to waste 
the excess cash flow in unprofitable investments (Jensen, 1986). Higher agency conflict of managers-shareholders occurs when there is a chance where managers hold higher free cash flow and use the excess cash flow into the project that does not fulfill shareholders' interests. Higher free cash flow leads to higher agency conflict of managers-shareholders and brings firms to bear more agency costs, further, it reduces performance. In the context of founding-family firms, the firms can improve performance they have lower free cash flow. Sitthipongpanich (2017) finds that founding-family firms reduce investment-free cash flow sensitivity to improve performance. Hau (2017) also finds that free cash flow reduces firms' performance.

H3b: Free cash flow moderates the effect of founding-family firms on performance

Assets growth captures investment opportunities had by firms (Fama \& French, 2002). Agency costs of managers-shareholders occur in higher investment opportunities firms where the managers tend to have underinvestment behavior and invest in unprofitable projects (Doukas \& Pantzalis, 2003). Similar to the free cash flow hypothesis, managers tend to waste firms' resources when firms grow and have excessive resources (Jensen, 1986). Higher investment opportunities lead to higher agency conflict of managers-shareholders and brings firms to bear more agency costs, further, it reduces performance. In the context of founding-family firms, the firms can improve performance they have lower investment opportunities. Hau (2017) finds that firms with higher investment opportunities have lower performance.

H3c: Assets growth moderates the effect of founding-family firms on performance

Collateral assets refer to the proportion of fixed assets. Fixed assets are a lower-risk investment since they will be used in a long-term period. For non-financial firms, fixed assets become the important assets to run the operational activities. When fixed assets are lower, there is a chance for managers to engage in a risky project. In the context of founding-family firms, where the founding-family shareholders tend to avoid risk, managers' behavior to engage in higher-risk investment becomes a conflict of interest between managers and shareholders. In this case, higher collateral assets mitigate the conflict of managers-shareholders and lead to agency costs reduction. Collateral assets also can improve performance by reducing the cost of external financing (Doukas \& Pantzalis, 2003; Kalash, 2019). Iltas and Demirgunes (2020) find that the proportion of fixed assets improves firms' performance.

H3d: Collateral assets moderate the effect of founding-family firms on performance

\section{Agency Costs of Majority-Minority Shareholders, Founding-Family Firms, and Performance}

One of the founding-family characteristics is concentrated ownership by the founding family. Although concentrated ownership mitigates the conflict between managers and shareholders, it raises conflict with minority shareholders (Andres, 2008). Agency conflict of majority-minority shareholders in founding-family firms happens because majority shareholders run the firms based on agenda that gives benefits only to family and it becomes costs to minority shareholders (Martin et al., 2017). In advance, majority shareholders of founding-family can give entrenchment effect where they will abuse their power over minority shareholders. Martin et al. (2017) find that founding-family ownership increases agency conflict of majority-minority shareholders.

Agency conflict of majority-minority shareholders leads to higher agency costs that can reduce performance. Agency cost of majority-minority shareholders refers to opportunity costs where majority shareholders of founding-family avoid performance improvement for family interests (Damayanti et al., 2018; Sanjaya, 2016). The opportunity costs include keeping the family 
manager with unprofessional managers that come from a collusive management system or ignoring innovation (PricewaterhouseCoopers, 2019) since innovation is close to the uncertainty that can lead to reputation reduction (Gottardo \& Moisello, 2017; Jiang et al., 2015). Sanjaya (2016) and Damayanti et al. (2018) find that abuse of power by majority shareholders of founding-family reduces firms' performance.

H4: Agency costs of majority-minority shareholders moderate the effect of founding-family firms on performance

\section{Research Framework}

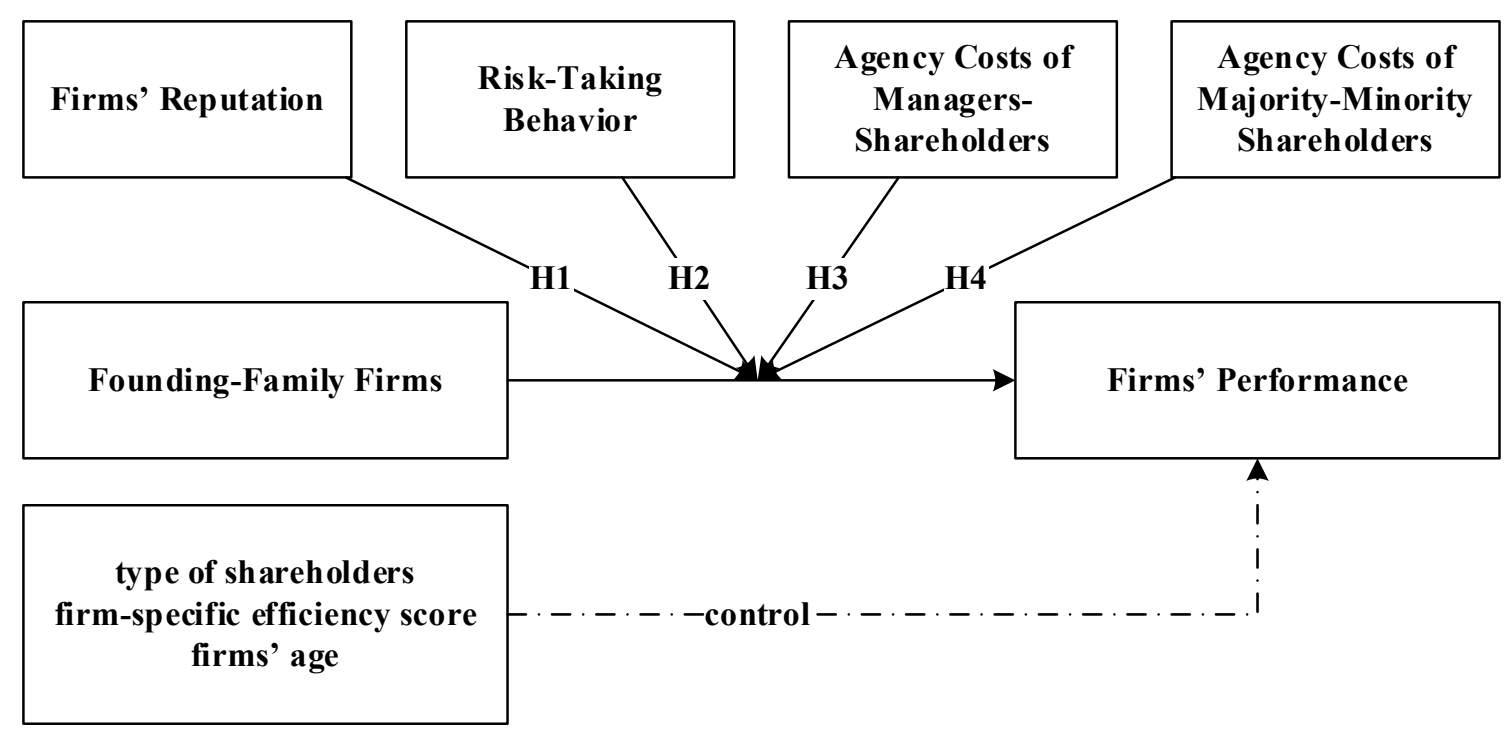

Figure 1. Research Framework

\section{Research Method}

\section{Sample and Data}

The research sample includes manufacturing firms listed on the Indonesian Stock Exchange. PricewaterhouseCoopers (2019) reports that mostly founding-family firms in Indonesia are manufacturing ones. Research data is accessed in the year 2016-2019 from firms' websites and the Indonesian Stock Exchange. The total sample is 412 firm-years as in table 1.

Table 1. Research Sample

\begin{tabular}{lc}
\hline Criteria of Sample & Firm-Year \\
\hline Manufacturing firms listed in IDX 2016-2019 & 436 \\
Incomplete data & $(24)$ \\
\hline Total & 412 \\
\hline
\end{tabular}

\section{Measurement of Firms Performance}

This research uses accounting-based and market-based firms' performance measurements (e.g. (Bambang \& Hermawan, 2012; Harjito et al., 2021; Juniarti, 2015; Martin-Reyna \& DuranEncalada, 2015; Ntoung et al., 2017; Zattoni et al., 2015). Accounting-based performance is a performance that is measured by using accounting numbers in the financial statement. Accounting- 
based performance is measured by return on assets (ROA). ROA captures the firms' activities to generate profit by utilizing the entire investment. ROA shows the firms' accounting rules to determine the measurement of profitability and productivity (Bambang \& Hermawan, 2012). ROA is calculated by earnings after tax divided by total assets.

Market-based performance is a performance that is measured by stock price as the investor or shareholder perception in the stock market. Market-based performance has been grown in firms' performance studies as a companion and complement for accounting-based performance (Bambang \& Hermawan, 2012). Market-based performance is measured by the market value to assets ratio (MVA). MVA is calculated by market capitalization divided by total assets. It captures the market perception of firms' performance relative to firms' assets.

\section{Measurement of Founding-Family Firms}

Founding-family firms are measured by a dummy variable where score 1 if firms are foundingfamily ones and score 0 if otherwise. Founding family refers to the founders and their family by blood, marriage, or legal process (Bambang \& Hermawan, 2012). The founders are a person or a group who (1) found the firms, or (2) acquires the majority firms' stake and change the business operations significantly (Andres, 2008). Founding-family firms are defined as the firms where founding-family involve in the decision-making process either as block-holder shareholders, firms' board members, or managers (Cheng, 2014). Based on the definition of founding-family firms, this research follows Andres (2008) who suggest the criteria of founding-family firms which are (1) one or more founding-family members hold share ownership of at least $25 \%$, (2) one or more founding-family members hold a position in firms' board. Andres (2008) explains that $25 \%$ of ownership is enough for founding-family act as block holders to give a significant impact in the general meeting of shareholders.

This research also examines the founding-family ownership and chief executive officer (hereafter CEO) status of the founding-family member. Founding-family ownership captures the founding family role as shareholders where their increased ownership lead to increased power to determine strategic decision in the general meeting of shareholders (Ntoung et al., 2017). Founding-family ownership is measured by share proportion held by founding-family members. CEOs have an important role in the firms since they are the main actor to execute the strategy in daily operational business. CEO status of founding-family member captures the founding-family member to execute business strategy and improve performance (Saidat et al., 2020). CEO status of a founding-family member is measured by a dummy variable where score 1 if CEO is the founding-family member and score 0 if otherwise.

\section{Measurement of Moderating Variables}

\section{Firm Reputation}

Firm reputation refers to the perception of customers, investors, employees, and the general public on the firm image (Lee \& Roh, 2012). It is measured by a dummy variable where score 1 if firms are reputable ones and score 0 if otherwise. This research defines the reputable firms based on firms' image research by Fortune Indonesia Magazine and Warta Ekonomi Magazine in the Indonesian Most Admired Companies Award that is held every year. Fortune Indonesia Magazine evaluates firms' image based on management quality, goods, and services quality, innovation, long-term value, financial performance, maintenance of employees, social and environmental responsibility, assets utilization, and regional and global business effectiveness (Warta Ekonomi, 2014). Warta Ekonomi Magazine evaluates firms' image based on corporate image, financial 
image, human resource image, and product and service image (Warta Ekonomi, 2015). This research determines reputable firms if firms get the Indonesian Most Admired Companies Award by Fortune Indonesia Magazine and/or Warta Ekonomi Magazine.

\section{Risk-Taking Behavior}

Risk-taking behavior refers to the firms' behavior to take a risky business strategy. Risk-taking behavior is measured by the standard deviation of ROA. The standard deviation of ROA shows that firms are more likely to engage in risky projects (Yung \& Chen, 2018). The standard deviation of ROA is calculated for a period of $t$ to $t+4$ ) (Yung \& Chen, 2018). A higher standard deviation of ROA indicates higher project risk covered by the firms.

\section{Agency Cost of Managers-Shareholders}

This research uses four proxies of manager agency cost of managers-shareholders. The first proxy is the operating expenses ratio that is measured by sales, general, and administration expenses ratio relative to total sales (Ang et al., 2000). Higher sales, general, and administration expenses ratio reflects higher managerial discretionary for consumption and utilization in operating expenses (Chamidah \& Asandimitra, 2017; Singh \& Davidson III, 2003). The second proxy is free cash flow. Higher free cash flow indicates a higher opportunity for managers to invest in unprofitable projects(Jensen, 1986). Free cash flow is measured by operating cash flow after capital expenditure relative to total assets (Kalash, 2019). The third proxy is assets growth. Higher assets growth indicates higher investment opportunity that also leads managers to invest in unprofitable projects(Jensen, 1986). Assets growth is measured by the differences of current and previous total assets relative to previous total assets (Fama \& French, 2002). The fourth proxy is collateral assets. Lower collateral assets show the lower proportion of fixed assets as a picture of a higher proportion of other risky investments that leads to higher agency conflict of managersshareholders. Collateral assets are measured by the ratio of fixed assets to total assets (Kalash, 2019).

\section{Agency Cost of Majority-Minority Shareholders}

Agency costs of majority-minority shareholders occur when there is a higher conflict between majority and minority shareholders. Sanjaya (2016) and Damayanti et al. (2018) suggest that the conflict of majority-minority shareholders is determined by the differences between control rights and cash-flow rights. If founding-family firms have control right above the cash flow right, conflict of majority-minority shareholders occurs. Agency cost of majority-minority shareholders is measured by cash flow right leverage that is calculated by control right minus cash flow right. Higher cash flow right leverage indicates higher agency costs of majority-minority shareholders.

Cash flow right is the sum of direct and indirect cash flow rights (La Porta et al., 1999, 2000). Direct cash flow right is measured by direct ownership proportion by founding-family in the firms. Indirect cash flow right is measured by multiplication ownership in each chain of indirect ownership. Control right is the sum of direct and indirect control rights (La Porta et al., 1999, 2000). Direct control right is measured by direct ownership proportion by founding-family in the firms. Indirect control right is measured by indirect ownership.

\section{Control Variables}

Control variables include the type of other shareholders, the firm-specific factor of efficiency score, and firms' age. Since one of the founding-family contributions comes from their role as shareholders, there is a probability that other shareholders also have a contribution to improve 
firms' performance, especially to manage the agency conflict (Andres, 2008). Type of other shareholders controls the other shareholders' contribution to the firms' performance. Type of other shareholders includes corporate shareholders and government shareholders. Corporate and government shareholders are measured by ownership proportion by corporate and government. The firm-specific factor of efficiency score controls the probability that firms' performance does not rely only on manager-specific factors but relies most on firm-specific factors (Simamora, 2021). The firm-specific factor of efficiency score is measured by decile rank of firm-specific efficiency score of data envelopment analysis by Demerjian et al. (2012). Firms' age controls the founding-family contribution in all business cycle periods since the firms are founded (Andres, 2008). Firms' age is measured logarithm natural of the number of listing years on the Indonesian Stock Exchange.

\section{Data Analysis}

This research uses random-effect regression to examine research hypotheses. Since fixedeffect regression needs a variation of founding-family status over the period, while there is a probability of homogeneity among founding-family firms, fixed-effect regression will be irrelevant (Andres, 2008). Since this research contains the moderating effect, this research also runs the multicollinearity test to examine the potential correlation between independent and interaction (moderating effect) variables. This research also uses common-effect regression as an alternative test. The regression model is as in equation 1 .

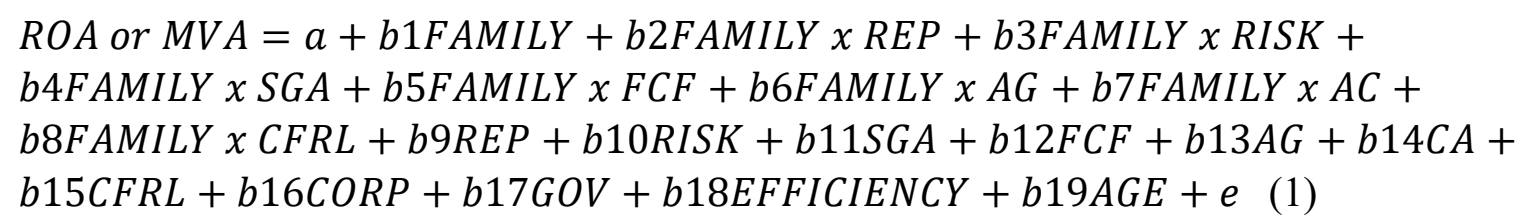

$R O A$ is the return on assets. $M V A$ is the market value to assets ratio. FAMILY is a foundingfamily firm. $R E P$ is a firm reputation. $R I S K$ is risk-taking behavior. $S G A$ is the sales, general, and administration expenses ratio. $F C F$ is free cash flow. $A G$ is assets growth. $C A$ is collateral assets. $C F R L$ is cash flow right leverage. $C O R P$ is corporate ownership. $G O V$ is governmental ownership. $E F F I C I E N C Y$ is a firm-specific efficiency score. $A G E$ is firm age. $\mathrm{H} 1$ is accepted if the coefficient of $b 2$ is positive and significant. $\mathrm{H} 2$ is accepted if the coefficient of $b 3$ is negative and significant. $\mathrm{H} 3 \mathrm{a}$ is accepted if the coefficient of $b 4$ is negative and significant. $\mathrm{H} 3 \mathrm{~b}$ is accepted if the coefficient of $b 5$ is negative and significant. $\mathrm{H} 3 \mathrm{c}$ is accepted if the coefficient of $b 6$ is negative and significant. $\mathrm{H} 3 \mathrm{~d}$ is accepted if the coefficient of $b 7$ is positive and significant. H4 is accepted if the coefficient of $b 8$ is negative and significant.

\section{Result and Discussion}

\section{Statistics Descriptive and Multicollinearity}

Table 2 captures statistics descriptive in panel A and Multicollinearity in panel B. In panel A, there are 272 founding-family firms-years or $66 \%$ of all samples while there are 140 non-family firms-years or $34 \%$ of all samples. The average values of return on assets (ROA) in foundingfamily firms and non-founding family firms respectively are 0.0631 and 0.0492 . Based on a statistical result, there is no difference in return on assets between founding-family firms and nonfounding family firms since there are determinant factors of founding-family firms that can 
improve or reduce the return on assets. The average values of market value to assets ratio (MVA) in founding-family firms and non-founding family firms respectively are 1.4090 and 1.0134 . Based on a statistical result, founding-family firms have a higher market value to assets ratio than non-founding family firms (significant in 0.10 ).

Table 2. Statistics Descriptive and Multicollinearity

\begin{tabular}{lccc}
\hline \multicolumn{2}{c}{ PANEL A. STATISTICS DESKRIPTIVE } \\
Mean \\
Type of Firms & Founding-Family Firms & Non-Family Firms & t-Statistic \\
\hline N & $\mathbf{2 7 2}(\mathbf{6 6 \%}$ of All Sample) & $\mathbf{1 4 0}(\mathbf{3 4 \%}$ of All Sample) & 0.9730 \\
\hline ROA & 0.0631 & 0.0492 & $1.8048^{* * *}$ \\
MVA & 1.4090 & 1.0134 & $2.4605^{* *}$ \\
REP & 0.1100 & 0.0400 & 0.7905 \\
RISK & 0.0457 & 0.0367 & 1.3077 \\
SGA & 0.1262 & 0.1489 & 1.0281 \\
FCF & -0.0102 & 0.0326 & 0.9993 \\
AG & 0.1912 & 0.1029 & 1.0175 \\
CA & 0.1458 & 0.3493 & $10.8670^{*}$ \\
CFRL & 0.5652 & 0.2105 & \\
\hline
\end{tabular}

Notes: *significant in $0.01, * *$ significant in $0.05, * * *$ significant in 0.10

PANEL B. MULTICOLLINEARITY

\begin{tabular}{lc} 
Variable & VIF \\
\hline FAMILY & 5.1870 \\
FAMILY x REP & 2.0822 \\
FAMILY x RISK & 5.5100 \\
FAMILY X SGA & 2.2866 \\
FAMILY x FCF & 1.7369 \\
FAMILY X AG & 5.0651 \\
FAMILY X CA & 1.3696 \\
FAMILY X CFRL & 5.5691 \\
REP & 2.4477 \\
RISK & 5.2487 \\
SGA & 1.7741 \\
FCF & 1.7354 \\
AG & 5.0651 \\
CA & 1.3694 \\
CFRL & 3.0489 \\
CORP & 1.4841 \\
GOV & 1.7882 \\
EFFICIENCY & 1.2996 \\
AGE & 1.3700 \\
\hline
\end{tabular}

Panel B shows the value of variance inflation factor (hereafter VIF) to examine the multicollinearity problem since this research involves the interaction variable as moderating effect. Multicollinearity problem refers to the significant relationship between one with other independent variables, and between independent variables and interaction variables. It occurs when the value 
of VIF is above 10. In panel $\mathrm{B}$, all independent variables and interaction variables have a value of VIF below 10. It indicates that there is no multicollinearity problem in this research.

Founding-Family Firms and Performance

Table 3. Random-Effect Regression of Founding-Family Firm and Performance

\begin{tabular}{|c|c|c|c|c|c|c|c|c|c|}
\hline Variable & $\begin{array}{c}\text { Expected } \\
\text { Sign }\end{array}$ & Coeff. & t-Statistic & Coeff. & t-Statistic & Coeff. & t-Statistic & Coeff. & $\begin{array}{l}\text { t-Statistic } \\
\text { (2) }\end{array}$ \\
\hline FAMILY & $+/-$ & 0.0003 & 0.0118 & 0.1298 & 0.5500 & 0.0980 & $2.1189^{* *}$ & 0.8730 & $1.8338^{* * *}$ \\
\hline FAMILY $x$ REP & + & & & & & 0.1330 & $2.3669 * *$ & 0.5942 & $1.7304 * * *$ \\
\hline FAMILY $x$ RISK & - & & & & & -14.8179 & $-1.8309 * * *$ & -1.0293 & $-2.0299 * *$ \\
\hline FAMILY $x S G A$ & - & & & & & -0.1831 & $-2.0257 * *$ & -1.4682 & $-1.8458 * * *$ \\
\hline$F A M I L Y x F C F$ & - & & & & & -0.2220 & $-2.5370 * *$ & -0.6705 & $-1.8254 * * *$ \\
\hline FAMILY $x A G$ & - & & & & & -0.1432 & $-2.1057 * *$ & -0.4517 & $-1.7426 * * *$ \\
\hline$F A M I L Y \times C A$ & + & & & & & 0.1380 & $2.4387 * *$ & 0.2743 & $1.7224 * * *$ \\
\hline$F A M I L Y \times C F R L$ & - & & & & & -0.1216 & $-2.4734 * *$ & -0.3483 & $-1.7976 * * *$ \\
\hline REP & + & & & & & 0.0400 & 1.0188 & 0.1965 & 0.9529 \\
\hline RISK & - & & & & & -14.3541 & $-1.7849 * * *$ & -0.3435 & -0.6829 \\
\hline SGA & - & & & & & -0.0073 & -0.1407 & -0.0057 & -0.0241 \\
\hline FCF & - & & & & & -0.2214 & $-2.5323 * *$ & -0.4716 & -1.2844 \\
\hline $\mathrm{AG}$ & - & & & & & -0.1432 & $-2.1055^{* *}$ & -0.4516 & $-1.7422 * * *$ \\
\hline $\mathrm{CA}$ & + & & & & & 0.0381 & 0.6725 & 0.0740 & 0.1577 \\
\hline CFRL & - & & & & & -0.0311 & -0.7611 & -0.8359 & -1.4244 \\
\hline CORP & + & -0.0023 & -0.0436 & 0.5086 & 0.5849 & -0.0350 & -1.0642 & 0.2353 & 0.4030 \\
\hline GOV & + & 0.0155 & 0.1537 & 1.4038 & 0.8588 & -0.0308 & -0.4546 & 0.7389 & 0.6523 \\
\hline EFFICIENCY & + & 0.1647 & $2.1510^{* *}$ & -0.0546 & -0.1690 & 0.1548 & $2.3434 * *$ & -0.1668 & -0.4524 \\
\hline AGE & + & 0.0020 & $2.5151 * *$ & 0.0313 & $2.8195^{*}$ & 0.0022 & $4.0714 *$ & 0.0490 & $5.8403 *$ \\
\hline Constant & & -0.1760 & & -0.4082 & & -0.1050 & & -1.2409 & \\
\hline Adjusted R-squared & & 0.0176 & & 0.0106 & & 0.2727 & & 0.0830 & \\
\hline F-statistic & & $2.4762 * *$ & & $1.8813 * * *$ & & $8.3401 *$ & & $2.7713 *$ & \\
\hline
\end{tabular}

Notes: *significant in $0.01, * *$ significant in $0.05, * * *$ significant in $0.10,(1)$ regression on ROA, (2) regression on MVA

In table 3, before involves the determinant factors of founding-family firms' performance as moderating variables, founding-family firms (FAMILY) has a coefficient value of 0.0003 with a t-statistic of 0.0118 (insignificant) in regression on return on assets (ROA) and coefficient value of 0.1298 with t-statistic of 0.5500 (insignificant) in regression on market value to assets ratio (MVA). It indicates that founding-family firms have no effect on firms' performance. It confirms this research argument where there are inconsistent previous findings of founding-family firms' performance that come from the absence of the determinant factors that can improve or reduce founding-family firms' performance.

After involves the determinant factors of founding-family firms' performance as moderating variables, the interactions of founding-family firms and firm reputation (FAMILY x REP) on return on assets (ROA) and market value to assets ratio (MVA) respectively have the coefficient values of 0.1330 and 0.5942 with t-statistics of 2.3669 (significant in 0.05 ) and 1.7304 (significant in 0.10 ). It indicates that $\mathrm{H} 1$ is accepted where firm reputation moderates the effect of founding- 
family firms on performance. Founding-family firms improve performance by using a higher firm reputation.

The interactions of founding-family firms and risk-taking behavior (FAMILY x RISK) on return on assets (ROA) and market value to assets ratio (MVA) respectively have the coefficient values of -14.8179 and -1.0293 with t-statistics of -1.8309 (significant in 0.10 ) and -2.0299 (significant in 0.05). It indicates that $\mathrm{H} 2$ is accepted where risk-taking behavior moderates the effect of founding-family firms on performance. Founding-family firms improve performance by implementing lower risk-taking behavior.

The interactions of founding-family firms and sales, general, and administration expenses ratio (FAMILY x SGA) on return on assets (ROA) and market value to assets ratio (MVA) respectively have the coefficient values of -0.1831 and -1.4682 with t-statistics of -2.0257 (significant in 0.05) and -1.4682 (significant in 0.10). It indicates that H3a is accepted where operating expenses moderate the effect of founding-family firms on performance. The interactions of founding-family firms and free cash flow (FAMILY x FCF) on return on assets (ROA) and market value to assets ratio (MVA) respectively have the coefficient values of -0.2220 and -0.6705 with t-statistics of -2.5370 (significant in 0.05 ) and -1.8254 (significant in 0.10 ). It indicates that $\mathrm{H} 3 \mathrm{~b}$ is accepted where free cash flow moderates the effect of founding-family firms on performance. The interactions of founding-family firms and assets growth (FAMILY x AG) on return on assets (ROA) and market value to assets ratio (MVA) respectively have the coefficient values of -0.1432 and -0.4517 with t-statistics of -2.1057 (significant in 0.05 ) and -1.7426 (significant in 0.10). It indicates that $\mathrm{H} 3 \mathrm{c}$ is accepted where assets growth moderates the effect of founding-family firms on performance. The interactions of founding-family firms and collateral assets (FAMILY x CA) on return on assets (ROA) and market value to assets ratio (MVA) respectively have the coefficient values of 0.1380 and 0.2743 with t-statistics of 2.4387 (significant in 0.05 ) and 1.7224 (significant in 0.10). It indicates that $\mathrm{H} 3 \mathrm{~d}$ is accepted where collateral assets moderate the effect of founding-family firms on performance. In general, H3 is accepted where agency costs of managers-shareholders moderate the effect of founding-family firms on performance. Since the reduction of sales, general, and administration expenses ratio, lower free cash flow, lower assets growth, and higher collateral assets capture lower agency costs of managers-shareholders; founding-family firms can improve performance by reducing agency costs of managers-shareholders.

The interactions of founding-family firms and cash flow right leverage (FAMILY x CFRL) on return on assets (ROA) and market value to assets ratio (MVA) respectively have the coefficient values of -0.1216 and -0.3483 with t-statistics of -2.4734 (significant in 0.05 ) and -1.7976 (significant in 0.10). Since higher cash flow right leverage captures higher agency costs of majority-minority shareholders, the result indicates that $\mathrm{H} 4$ is accepted where agency costs of majority-minority shareholders moderate the effect of founding-family firms on performance. Founding-family firms improve can performance by reducing agency costs of majority-minority shareholders.

\section{Founding-Family CEO and Ownership}

Founding family role can give a significant impact on the firms' business by acting as a CEO or the shareholders. While founding-family shareholders give an impact to strategic decisionmaking in a general meeting of shareholders, founding-family CEO gives an impact on business strategy execution in daily operational activities. Founding-family shareholders are captured by founding-family and founding-family CEO is captured by CEO status as a founding-family 
member. The role of the founding-family CEO can be seen in table 4 while the role of foundingfamily shareholders can be seen in table 5 .

Table 4. Random-Effect Regression of Founding-Family CEO and Performance

\begin{tabular}{|c|c|c|c|c|c|c|c|c|c|}
\hline Variable & $\begin{array}{c}\text { Expected } \\
\text { Sign } \\
\end{array}$ & Coeff. & $\begin{array}{l}\text { t-Statistic } \\
\text { (1) }\end{array}$ & Coeff. & t-Statistic & Coeff. & $\begin{array}{l}\text { t-Statistic } \\
\text { (1) }\end{array}$ & Coeff. & $\begin{array}{l}\text { t-Statistic } \\
\text { (2) }\end{array}$ \\
\hline FAMILY CEO & $+/-$ & 0.0060 & 0.2603 & 0.1175 & 0.5034 & 0.0485 & 0.9369 & 0.7703 & 1.4920 \\
\hline FAMILY CEO $\times$ REP & + & & & & & 0.0712 & 1.1070 & 0.2104 & 0.5546 \\
\hline FAMILY CEO $x$ RISK & - & & & & & -0.7952 & $-2.0616^{* *}$ & -0.6019 & -0.8371 \\
\hline FAMILY CEO $\times$ SGA & - & & & & & -0.2216 & $-1.9206^{* * *}$ & -0.6724 & $-1.8236 * * *$ \\
\hline FAMILY CEO $x$ FCF & - & & & & & -0.2143 & $-2.2050 * *$ & -0.4254 & $-2.3000 * *$ \\
\hline FAMILY CEO $\times A G$ & - & & & & & -0.0788 & $-1.6846 * * *$ & -0.3354 & $-1.7352 * * *$ \\
\hline FAMILY CEO $\times$ CA & + & & & & & 0.1513 & $2.4291 * *$ & 0.7300 & $1.7915 * * *$ \\
\hline FAMILY CEO $\times$ CFRL & - & & & & & -0.1448 & $-3.1394 *$ & -1.7571 & $-2.7814^{*}$ \\
\hline REP & + & & & & & 0.1135 & $3.3361 *$ & 0.4154 & $2.2447 * *$ \\
\hline RISK & - & & & & & -0.7185 & $-11.4801 *$ & -0.0272 & -0.0217 \\
\hline SGA & - & & & & & -0.0267 & -0.6083 & -0.0964 & -0.4164 \\
\hline FCF & - & & & & & -0.0005 & -0.1646 & -0.0016 & -0.1592 \\
\hline $\mathrm{AG}$ & - & & & & & 0.0000 & -0.4981 & -0.0001 & -0.8198 \\
\hline $\mathrm{CA}$ & + & & & & & 0.0000 & 0.0860 & 0.0002 & 0.2813 \\
\hline CFRL & - & & & & & -1.3513 & $-2.8717^{*}$ & -0.0155 & -0.5843 \\
\hline CORP & + & -0.0061 & -0.1134 & 0.5418 & 0.6162 & -0.0324 & -0.9502 & 0.1658 & 0.2528 \\
\hline GOV & + & 0.0086 & 0.0861 & 1.3809 & 0.8465 & -0.0343 & -0.5335 & 0.0938 & 0.0762 \\
\hline EFFICIENCY & + & 0.1641 & $2.1506^{* *}$ & -0.0554 & -0.1715 & 0.1028 & $1.7764 * * *$ & -0.2482 & -0.6762 \\
\hline AGE & + & 0.0020 & $2.4943 * *$ & 0.0313 & $2.8189^{*}$ & 0.0023 & $4.4181^{*}$ & 0.0466 & $5.1623^{*}$ \\
\hline Constant & & -0.1693 & & -0.3924 & & -0.1893 & & -0.1900 & \\
\hline Adjusted R-squared & & 0.0178 & & 0.0105 & & 0.2736 & & 0.0591 & \\
\hline F-statistic & & $2.4913 * *$ & & $1.8733 * * *$ & & $8.3729 *$ & & $2.2291 *$ & \\
\hline
\end{tabular}

In table 4, after involves the determinant factors of founding-family firms' performance as moderating variables, firm reputation has no moderating effect on founding-family CEO and firms' performance. The result is not consistent with the main findings in table 3. The main findings in table 3 are sensitive if reputable founding-family firms involve founding-family members as a CEO to improve both accounting-based and market-based firms' performance. Founding-family role as a CEO more occurs to improve accounting-based than market-based performances, especially when founding-family firms have a higher reputation. The main findings in table 3 are sensitive if reputable founding-family firms involve founding-family CEO to improve market-based performance. On the other hand, agency costs of manager-shareholders (operating expenses, free cash flow, assets growth, collateral assets) and majority-minority shareholders moderate the effect of founding-family CEO on performance. It is consistent with the main findings in table 3. 
Table 5. Random-Effect Regression of Founding-Family Ownership and Performance

\begin{tabular}{|c|c|c|c|c|c|c|c|c|c|}
\hline Variable & $\begin{array}{c}\text { Expected } \\
\text { Sign }\end{array}$ & Coeff. & $\begin{array}{l}\text { t-Statistic } \\
\text { 1) }\end{array}$ & Coeff. & t-Statistic & Coeff. & t-Statistic & Coeff. & $\begin{array}{l}\text { t-Statistic } \\
\text { (2) }\end{array}$ \\
\hline FAMILY OWN & $+/-$ & 0.0154 & 0.4905 & 0.2933 & 1.3325 & 0.1907 & $3.0519^{*}$ & 1.4423 & $2.9910^{*}$ \\
\hline FAMILY OWN $x$ REP & + & & & & & 0.2449 & $2.9359^{*}$ & 2.3958 & $4.4954 *$ \\
\hline FAMILY OWN $x$ RISK & - & & & & & -1.9132 & $-4.1167 *$ & -12.3589 & $-1.7585 * * *$ \\
\hline FAMILY OWN $x$ SGA & - & & & & & -0.1194 & $-5.6159 *$ & -0.4590 & $-2.2772 *$ \\
\hline FAMILY OWN $x$ FCF & - & & & & & -0.3509 & $-3.0390 *$ & -0.3294 & $-1.7497 * * *$ \\
\hline FAMILY OWNXAG & - & & & & & -0.2111 & $-2.8561^{*}$ & -0.2176 & -0.7055 \\
\hline FAMILY OWN $x$ CA & + & & & & & 0.1499 & $2.1248 * *$ & 0.5442 & $1.9363 * * *$ \\
\hline FAMILY OWN $x$ CFRL & - & & & & & -0.2134 & $-2.6758^{*}$ & -0.7885 & $-1.7687 * * *$ \\
\hline REP & + & & & & & 0.0254 & 0.6923 & 0.0920 & 0.4631 \\
\hline RISK & - & & & & & -0.8721 & $-2.2794 * *$ & -9.7986 & $-1.6882 * * *$ \\
\hline SGA & - & & & & & -0.0726 & -1.4798 & -0.0688 & -0.2915 \\
\hline FCF & - & & & & & -0.2404 & $-3.0334^{*}$ & -0.2278 & -0.6794 \\
\hline AG & - & & & & & -0.1450 & $-2.8557^{*}$ & -0.1494 & -0.7050 \\
\hline $\mathrm{CA}$ & + & & & & & 0.1030 & $2.1255^{* *}$ & 0.2362 & 0.5918 \\
\hline CFRL & - & & & & & -0.0077 & -0.2298 & -0.6987 & -1.5763 \\
\hline CORP & + & -0.0005 & -0.0099 & 0.4947 & 0.5712 & -0.0606 & $-1.8978 * * *$ & 0.2049 & 0.3579 \\
\hline GOV & + & 0.0253 & 0.2562 & 1.4317 & 0.8863 & -0.0817 & -1.2965 & 0.5971 & 0.5478 \\
\hline EFFICIENCY & + & 0.1651 & $2.1687 * *$ & -0.0464 & -0.1436 & 0.1165 & $1.7683^{* * *}$ & -0.3115 & -0.8507 \\
\hline AGE & + & 0.0020 & $2.4911^{* *}$ & 0.0309 & $2.7893^{*}$ & 0.0022 & $4.2662^{*}$ & 0.0460 & $5.5685^{*}$ \\
\hline Constant & & -0.1822 & & -0.4206 & & -0.0687 & & -0.8517 & \\
\hline Adjusted R-squared & & 0.0183 & & 0.0139 & & 0.3240 & & 0.1118 & \\
\hline F-statistic & & $2.5333 * *$ & & $2.1618 * * *$ & & $10.3814^{*}$ & & $3.4639^{*}$ & \\
\hline
\end{tabular}

Notes: *significant in $0.01, * *$ significant in $0.05, * * *$ significant in $0.10,(1)$ regression on ROA, (2) regression on MVA

In table 5, after involving the determinant factors of founding-family firms' performance as moderating variables, firm reputation, risk-taking behavior, agency costs of manager-shareholders (operating expenses, free cash flow, collateral assets), and agency costs of majority-minority shareholders moderate the effect of founding-family CEO on performance. It is consistent with the main findings in table 3. On the other hand, assets growth moderates the effect of founding-family ownership on accounting-based performance but not on market-based performance. the main findings in table 3 are sensitive if agency costs of managers-shareholders are measured by assets growth, especially for market-based performance.

\section{Additional Test}

The additional test aims to examine the moderating role of founding-family firms' determinant factors of founding-family firms' performance in different conditions. The first additional test considers the definition of family firms in general. Some studies give a different definition to family firms. On one hand, "family" refers to the firms' founders and their family as in this research context (e.g.(Andersson et al., 2018; Andres, 2008; Bambang \& Hermawan, 2012). On the other hand, "family" refers to public-family that captures both founding and non-founding (e.g.(La Porta et al., 2000; Setia-Atmaja et al., 2009; Vieira, 2020). This research examines the public-family as well to ensure if the main result is still consistent in the condition where the family firms refer to the public-family involvement in the firms. The second additional test considers 
another regression model to examine the moderating role of determinant factors of foundingfamily firms' performance. To ensure the main findings' robustness, this research also runs a common-effect regression test to ensure if random-effect results are consistent with commoneffect ones. The common-effect regression test is initiated by heteroscedasticity, autocorrelation, and multicollinearity tests. An additional test of public-family firms is as in table 6 while the common-effect regression test is as in table 7.

Table 6. Random-Effect Regression of Public-Family Firm and Performance

\begin{tabular}{|c|c|c|c|c|c|c|c|c|c|}
\hline Variable & $\begin{array}{c}\text { Expected } \\
\text { Sign }\end{array}$ & Coeff. & $\begin{array}{l}\text { t-Statistic } \\
\text { 1) }\end{array}$ & Coeff. & t-Statistic & Coeff. & $\begin{array}{l}\text { t-Statistic } \\
\text { (1) }\end{array}$ & Coeff. & $\begin{array}{l}\text { t-Statistic } \\
\text { (2) }\end{array}$ \\
\hline FAMILY & $+/-$ & 0.0001 & 0.0054 & 0.8408 & $2.0136^{* *}$ & 0.1123 & $2.3038 * *$ & 1.0420 & 1.6144 \\
\hline PUBLIC FAMILY $x$ REP & + & & & & & 0.1333 & $2.1904 * *$ & 0.5773 & $2.3125 * *$ \\
\hline PUBLIC FAMILY $x$ RISK & - & & & & & -1.4773 & $-2.7148 *$ & -3.7301 & $-1.8114 * * *$ \\
\hline PUBLIC FAMILYX SGA & - & & & & & -0.1478 & $-1.6544 * * *$ & -0.5658 & $-1.6759 * * *$ \\
\hline PUBLIC FAMILY $x$ FCF & - & & & & & -0.3131 & $-3.8840 *$ & -0.9277 & $-2.4249 * *$ \\
\hline PUBLIC FAMILY $x A G$ & - & & & & & -0.1451 & $-1.9991 * *$ & -0.5373 & $-1.7965 * * *$ \\
\hline PUBLIC FAMILY $x$ CA & + & & & & & 0.1401 & $2.3870 * *$ & 0.4448 & $1.9933 * *$ \\
\hline PUBLIC FAMILY $x$ CFRL & - & & & & & -0.1148 & $-1.8970 * * *$ & -0.9106 & $-1.7426 * * *$ \\
\hline REP & + & & & & & 0.0688 & $1.8932 * * *$ & 0.2067 & 1.0009 \\
\hline RISK & - & & & & & -0.7925 & -1.4652 & -2.8373 & -0.2838 \\
\hline SGA & - & & & & & -0.0270 & -0.5317 & -0.0486 & -0.2030 \\
\hline $\mathrm{FCF}$ & - & & & & & -0.3124 & $-3.8784 *$ & -0.5288 & -1.3826 \\
\hline $\mathrm{AG}$ & - & & & & & -0.1451 & $-1.9988 * *$ & -0.4372 & -1.4618 \\
\hline $\mathrm{CA}$ & + & & & & & 0.0401 & 0.6838 & 0.1451 & 0.2774 \\
\hline CFRL & - & & & & & 0.0466 & 0.8804 & -0.8570 & -0.8776 \\
\hline CORP & + & -0.0024 & -0.0457 & 0.1448 & 0.1663 & -0.0320 & -0.9772 & -0.1558 & -0.2539 \\
\hline GOV & + & 0.0150 & 0.1479 & 0.1968 & 0.1176 & -0.0410 & -0.6071 & -0.4723 & -0.3960 \\
\hline EFFICIENCY & + & 0.1647 & $2.1608^{* *}$ & -0.0622 & -0.1925 & 0.1159 & $1.7533 * * *$ & -0.1338 & $-0.3586^{*}$ \\
\hline AGE & + & 0.0020 & $2.4833 * *$ & 0.0285 & $2.5547 * *$ & 0.0019 & $3.6011^{*}$ & 0.0456 & 5.3019 \\
\hline Constant & & -0.1755 & & 0.6219 & & -0.0977 & & 0.3397 & \\
\hline Adjusted R-squared & & 0.0176 & & 0.0200 & & 0.2820 & & 0.0689 & \\
\hline F-statistic & & $2.4722 * *$ & & $2.6778 * *$ & & $8.6870^{*}$ & & $2.4477 *$ & \\
\hline
\end{tabular}

In table 6, firm reputation, risk-taking behavior, agency costs of manager-shareholders (operating expenses, free cash flow, collateral assets), and agency costs of majority-minority shareholders moderate the effect of public-family firms on performance. In general, the results in table 6 are consistent with the main findings in table 3. 
Table 7. Common-Effect Regression of Founding-Family Firm and Performance

\begin{tabular}{|c|c|c|c|c|c|c|c|c|c|}
\hline \multirow{2}{*}{$\begin{array}{l}\text { Variable } \\
\text { FAMILY }\end{array}$} & \multirow{2}{*}{$\begin{array}{c}\text { Expected } \\
\text { Sign } \\
+/-\end{array}$} & Coeff. & $\begin{array}{l}\text { t-Statistic } \\
\text { (1) }\end{array}$ & Coeff. & t-Statistic & Coeff. & $\begin{array}{l}\text { t-Statistic } \\
\text { (1) }\end{array}$ & Coeff. & t-Statistic \\
\hline & & 0.0025 & 0.1389 & 0.0311 & 0.1505 & 0.2997 & 0.5455 & 0.0980 & $2.0082 * *$ \\
\hline$F A M I L Y \times R E P$ & + & & & & & 0.1330 & $2.2433 * *$ & 4.7356 & $7.0940^{*}$ \\
\hline FAMILY $x$ RISK & - & & & & & -1.0293 & $-1.9238 * * *$ & -5.9813 & $-1.9767 \% *$ \\
\hline FAMILY $x S G A$ & - & & & & & -0.1831 & $-1.9198 * * *$ & -2.7959 & $-2.6021^{*}$ \\
\hline FAMILY $x$ FCF & - & & & & & -0.2220 & $-2.4045 * *$ & -4.6332 & $-4.4564 *$ \\
\hline$F A M I L Y \times A G$ & - & & & & & -0.1432 & $-1.9957 * * *$ & -2.9502 & $-3.6503 *$ \\
\hline$F A M I L Y x C A$ & + & & & & & 0.1380 & $2.3113 \% *$ & 0.4445 & $2.0900 * *$ \\
\hline FAMILY $\times C F R L$ & - & & & & & -0.1216 & $-2.3441^{* *}$ & -0.4126 & $-2.2393 * *$ \\
\hline REP & + & & & & & 0.0400 & 0.9655 & 0.3668 & 0.7863 \\
\hline RISK & - & & & & & -0.3435 & -0.6472 & -5.9742 & -0.9994 \\
\hline SGA & - & & & & & -0.0073 & -0.1334 & -0.2214 & $-2.4000 * *$ \\
\hline FCF & - & & & & & -0.0826 & -0.1343 & -4.6413 & $-4.4667 *$ \\
\hline $\mathrm{AG}$ & - & & & & & -0.1432 & $-1.9955^{* *}$ & -2.9500 & $-3.6501 *$ \\
\hline $\mathrm{CA}$ & + & & & & & 0.0381 & 0.6374 & 0.2444 & 0.3634 \\
\hline CFRL & - & & & & & -0.0311 & -0.7213 & -0.5446 & -1.1202 \\
\hline CORP & + & -0.0044 & -0.1164 & -0.2348 & -0.5300 & -0.0350 & -1.0086 & -0.0734 & -0.1879 \\
\hline GOV & + & 0.0152 & 0.2088 & 0.1098 & 0.1295 & -0.0308 & -0.4309 & -0.2171 & -0.2699 \\
\hline EFFICIENCY & + & 0.1365 & $1.9123 * * *$ & 0.3256 & 0.3927 & 0.1048 & 1.5037 & 0.7070 & 0.9004 \\
\hline AGE & + & 0.0022 & $3.8339^{*}$ & 0.0741 & $11.0478^{*}$ & 0.0022 & $3.8610^{*}$ & 0.0564 & $8.9236^{*}$ \\
\hline Constant & & -0.1574 & & -1.7530 & & -0.1050 & & -2.2198 & \\
\hline Adjusted R-squared & & 0.0380 & & 0.2375 & & 0.2727 & & 0.4587 & \\
\hline F-statistic & & $4.2448^{*}$ & & $17.5262 *$ & & $8.3401^{*}$ & & $26.6063^{*}$ & \\
\hline Sig. of white test & & 0.8784 & & 0.8873 & & 0.4139 & & 0.4431 & \\
\hline Sig. of serial correlati & n LM test & 0.5564 & & 0.4877 & & 0.2123 & & 0.2289 & \\
\hline VIF & & Below 10 & & Below 10 & & Below 10 & & Below 10 & \\
\hline
\end{tabular}

Notes: *significant in $0.01, * *$ significant in $0.05, * * *$ significant in $0.10,(1)$ regression on ROA, (2) regression on MVA

In table 7, firm reputation, risk-taking behavior, agency costs of manager-shareholders (operating expenses, free cash flow, collateral assets), and agency costs of majority-minority shareholders moderate the effect of founding-family firms on performance. In general, the results in table 7 are consistent with the main findings in table 3.

\section{Discussion}

This research examines the determinant factors of founding-family firms' performance. It is important to examine determinant factors founding-family firms' performance to determine when firms can improve optimal performance or experience performance reduction. Based on data analysis, founding-family firms can improve performance when they have a higher firm reputation, lower risk-taking behavior, and lower agency costs. The result is consistent with previous studies that find, higher firm reputation (Lee \& Roh, 2012; Sánchez \& de Vega, 2018), lower risk-taking behavior (Miller \& Bromiley, 1990; Olaniran et al., 2016), and lower agency costs (Damayanti et al., 2018; Hoang et al., 2019; Jabbary et al., 2013; Sanjaya, 2016) leads to higher firms' performance. In this case, all research hypotheses are accepted. Furthermore, the founding-family 
role as shareholders occurs in all firms' determinant factors, while the founding-family role as CEO occurs more in factors of agency costs.

Founding-family firms have unique characteristics that can improve or reduce firms' performance. Founding-family firms have a family value of socioemotional wealth where the firms are run to fulfill the emotional needs, the family members' wealth, and firms' reputation. The family value leads firms to have a higher reputation and lower risk-taking behavior since the firms will be passed down to the next family generation in the future. Higher reputation and lower risk-taking behavior become the competitive advantages for firms to avoid uncertainty and achieve optimal performance. Founding-family involvement in ownership structure and firms' management also gives benefits of interest alignment between shareholders and managers since they have the same family value. Interest alignment between shareholders and managers leads to lower agency costs of managers-shareholders and increases performance. However, interest alignment does not happen between majority-minority shareholders relationship. In the founding-family firms, majority shareholders of founding-family have an interest in family needs while minority shareholders of non-family have an interest in public needs. In this case, agency costs of majorityminority shareholders occur. It will reduce firms' performance, especially when majority shareholders of founding-family do the power abuse to make an ineffective business decision. The result implies the founding-family role to maintain the firms' benefits and mitigate the firms' costs that contribute to performance achievement.

This research is the first research that provides a comprehensive picture of determinant factors founding-family firms' performance in Indonesia. This finding confirms previous findings gap (e.g.(Bambang \& Hermawan, 2012; Harjito et al., 2021; Juniarti, 2015; Martin-Reyna \& DuranEncalada, 2015; Ntoung et al., 2017; Zattoni et al., 2015) that does not provide a comprehensive picture of determinant factors founding-family firms' performance. However, the result cannot explain which founding-family generation that can give an optimal performance to the firms since there is a data limitation for this research. The result also does not capture the possibility of internal family conflict between founding-family members. In the future, there is an opportunity to examine the role of founding-family in a different generation and consider the internal family conflict that can lead to higher agency costs.

\section{Conclusions}

The family business is playing an important role in Indonesia. It is important to find out what are founding-family firms' costs and benefits to achieve performance. This research aims to examine the factors that moderate the effect of founding-family firms on performance. Based on data analysis, firm reputation, risk-taking behavior, agency costs of mangers-shareholders, and agency costs of majority-minority shareholders moderates the effect of the founding-family firms on performance. It indicates that founding-family firms can achieve higher performance if they promote a higher firm reputation, lower risk-taking behavior, and lower agency costs. Further, the result shows that determinant factors of founding-family firms' performance occur more in founding-family shareholders while agency costs occur more in founding-family CEO.

This research implies founding-family firms make a strategy that can optimize the competitive advantage of firm reputation, lower business risk, and lower agency costs of mangersshareholders. Founding-family firms are also expected to make a strategy that can mitigate agency costs of majority-minority shareholders by aligning the family and public interests. This research also implies CEO, especially founding-family CEO. This research finds that the founding-family 
CEO fails to utilize the firm reputation as a competitive advantage. Founding-family CEO is expected to improve skill and knowledge on how to use firm reputation as a valuable asset for performance improvement. Founding-family firms can consider developing the professional recruitment and training program to enhance CEO make a good business relationship to firms' stakeholders by using positive stakeholders' perception on firm reputation.

This research has limitations. First, this research does not consider the founding-family generation. A different generation has different characteristics. For example, as a first-generation, founders have more knowledge and experience of business firms since the firms are founded than the second or third generation. Different levels of knowledge and experience give different contributions to firms' performance. Future research is expected to consider founding-family generation in ownership structure and management involvement. Second, this research does not consider the possibility of conflict between family members. Family conflict can rise the potential of different types of agency costs (Li \& Zuo, 2020). Future research is expected to consider the family problem such as a different role and position of each family member in the firms.

\section{References}

Alves, C., \& Gama, A. (2020). Family Business Performance: A Perspective of Family Influence. Review of Business Management, 22(1), 163-182. https://doi.org/10.7819/rbgn.v22i1.4040

Anderson, R. C., \& Reeb, D. M. (2003). Founding-Family Ownership and Firm Performance: Evidence from the S\&P 500. The Journal of Finance, 58(3), 1301-1328. https://doi.org/10.1111/1540-6261.00567

Andersson, F. W., Johansson, D., Karlsson, J., Lodefalk, M., \& Poldahl, A. (2018). The Characteristics of Family Firms: Exploiting Information on Ownership, Kinship, and Governance Using Total Population Data. Small Business Economics, 51(3), 539-556. https://doi.org/10.1007/s11187-017-9947-6

Andres, C. (2008). Large Shareholders and Firm Performance-An Empirical Examination of Founding-Family Ownership. Journal of Corporate Finance, 14(4), 431-445. https://doi.org/10.1016/j.jcorpfin.2008.05.003

Ang, J. S., Cole, R. A., \& Lin, J. W. (2000). Agency Costs and Ownership Structure. The Journal of Finance, 55(1), 81-106. https://doi.org/10.1111/0022-1082.00201

Armanto, B., Tiono, K. M., \& Suthiono, H. (2014). The Stickiness of Selling, General, and Administrative Costs in the Indonesian Companies. International Research Journal of Business Studies, 7(1), 39-53. https://doi.org/10.21632/irjbs.7.1.39-53

Bambang, M., \& Hermawan, M. S. (2012). Founding Family Ownership and Firm Performance: Empirical Evidence from Consumer Goods Industry in Indonesia. Journal of Applied Finance and Accounting, 4(2), 112-131.

Berrone, P., Cruz, C., Gomez-Mejia, L. R., \& Larraza-Kintana, M. (2010). Socioemotional Wealth and Corporate Responses to Institutional Pressures: Do Family-Controlled Firms Pollute Less? Administrative Science Quarterly, 52-113. https://doi.org/10.2189/asqu.2010.55.1.82

Block, J. (2010). Family Management, Family Ownership, and Downsizing: Evidence from S\&P 500 Firms. Family Business Review, 23(2), 109-130. https://doi.org/10.1177/089448651002300202

Cao, Y., Myers, J. N., Myers, L. A., \& Omer, T. C. (2015). Company Reputation and the Cost of Equity Capital. Review of Accounting Studies, 20(1), 42-81. https://doi.org/10.1007/s11142014-9292-9

Chamidah, N., \& Asandimitra, N. (2017). The Determinant of Agency Cost in Indonesia. International Journal of Economic Research, 14(1), 449-463.

Chattopadhyay, P., Glick, W. H., \& Huber, G. P. (2001). Organizational Actions in Response to 
Threats and Opportunities. Academy of Management Journal, 44(5), 937-955. https://doi.org/10.2307/3069439

Cheng, Q. (2014). Family Firm Research - A Review. China Journal of Accounting Research, 7(3), 149-163. https://doi.org/10.1016/j.cjar.2014.03.002

Cole, S. (2013). The Impact of Reputation on Market Value. World Economics, 3(3), 47-68.

Craig, J. B., Dibrell, C., \& Davis, P. S. (2008). Leveraging Family-Based Brand Identity to Enhance Firm Competitiveness and Performance in Family Businesses. Journal of Small Business Management, 46(3), 351-371. https://doi.org/10.1111/j.1540-627X.2008.00248.x

Damayanti, T., Lindrianasari, Komalasari, A., Dewi, F. G., \& Gamayuni, R. R. (2018). Entrenchment Effect and Financial Performance in Indonesia Family Listed Companies. Review of Integrative Business and Economics Research, 7(S2), 152-166.

Deloitte. (2019). Long-Term Goals, Meet Short-Term Drive: Global Family Business Survey 2019. Deloitte Development LLC.

Demerjian, P., Lev, B., \& McVay, S. (2012). Quantifying Managerial Ability: A New Measure and Validity Tests. Management Science, 58(7), 1229-1248. https://doi.org/10.1287/mnsc. 1110.1487

Doukas, J. A., \& Pantzalis, C. (2003). Geographic Diversification and Agency Costs of Debt of Multinational Firms. Journal of Corporate Finance, 9(1), 59-92. https://doi.org/10.1016/S0929-1199(01)00056-6

Dyer, W. G., \& Whetten, D. A. (2006). Family Firms and Social Responsibility: Preliminary Evidence from the S\&P 500. Entrepreneurship Theory and Practice, 30(6), 785-802. https://doi.org/10.1111/j.1540-6520.2006.00151.x

Faisal, Fachrudin, K. A., \& Absah, Y. (2021). Analysis of Effect of Capital Expense Efficiency, Operating Expense Efficiency and Exchange Rate Difference to Financial Performance in PT.Telkomsel. International Journal of Research and Review, 8(2), 155-162.

Fama, E. F., \& French, K. R. (2002). Testing Trade-Off and Pecking Order Predictions About Dividends and Debt. Review of Financial Studies, 15(1), 1-33. https://doi.org/10.1093/rfs/15.1.1

Gottardo, P., \& Moisello, A. M. (2017). Family Firms, Risk-Taking and Financial Distress. Problems and Perspectives in Management, 15(2), 168-177. https://doi.org/10.21511/ppm.15(2-1).2017.01

Harjito, D. A., Santoso, A. R. C., \& McGowan Jr., C. B. (2021). The Effect Of Corporate Governance And Corporate Strategy On Family Firm Performance In Indonesia. Ournal of Applied Business Research, 37(1), 11-16.

Hau, L. L. (2017). Free Cashflow and Firm Performance: Evidence from Sectoral Levels for Vietnamese Listed Firms. International Journal of Advanced Engineering, Management and Science, 3(4), 296-300. https://doi.org/10.24001/ijaems.3.4.2

Hoang, L. D., Tuan, T. M., Nha, P. V. T., Nha, P. V. T., \& Phuong, T. T. (2019). Impact of Agency Costs on Firm Performance: Evidence from Vietnam. Organizations and Markets in Emerging Economies, 10(2), 294-309. https://doi.org/10.15388/omee.2019.10.15

Iltas, Y., \& Demirgunes, K. (2020). Asset Tangibility and Financial Performance: A Time Series Evidence. Ahi Evran Üniversitesi Sosyal Bilimler Enstitüsü Dergisi, 6(2), 345-364. https://doi.org/10.31592/aeusbed.731079

Jabbary, H., Hajiha, Z., \& Labeshka, R. H. (2013). Investigation of the Effect of Agency Costs on Firm Performance of Listed Firms in Tehran Stock Exchange. European Online Journal of Natural and Social Sciences, 2(3), 771-776.

Jensen, M. C. (1986). Agency Costs of Free Cash Flow, Corporate Finance, and Takeovers. The American Economic Review, 76(2), 323-329.

Jensen, M. C., \& Meckling, W. H. (1976). Theory of the firm: Managerial behavior, agency costs and ownership structure. Journal of Financial Economics, 3(4), 305-360. 
https://doi.org/10.1016/0304-405X(76)90026-X

Jiang, F., Jiang, Z., Kim, K. A., \& Zhang, M. (2015). Family-Firm Risk-Taking: Does Religion Matter? Journal of Corporate Finance, 33, 260-278. https://doi.org/10.1016/j.jcorpfin.2015.01.007

Juniarti, N. A. (2015). The Negative Impact of Family Ownership Structure on Firm Value in the Context of Indonesia. International Journal of Business and Globalisation, 15(4), 446. https://doi.org/10.1504/IJBG.2015.072517

Kalash, I. (2019). Firm Leverage, Agency Costs and Firm Performance: An Empirical Research on Service Firms in Turkey. Journal of the Human and Social Science Researches, 8(1), 624636. https://doi.org/10.15869/itobiad.513268

Kalm, M., \& Gomez-Mejia, L. R. (2016). Socioemotional Wealth Preservation in Family Firms. Revista de Administração, 51(4), 409-411. https://doi.org/10.1016/j.rausp.2016.08.002

La Porta, R., Lopez-de-Silanes, F., Shleifer, A., \& Vishny, R. (1999). The Quality of Government. Journal of Law, Economics, \& Organization, 15(1), 222-279.

La Porta, R., Lopez-de-Silanes, F., Shleifer, A., \& Vishny, R. W. (2000). Agency Problems and Dividend Policies around the World. The Journal of Finance, 55(1), 1-33. https://doi.org/10.1111/0022-1082.00199

Lee, J., \& Roh, J. J. (2012). Revisiting Corporate Reputation and Firm Performance Link. Benchmarking: An International Journal, 19(4/5), 649-664. https://doi.org/10.1108/14635771211258061

Levenburg, N. M. (2006). Benchmarking Customer Service on the Internet: Best Practices from Family Businesses. Benchmarking: An International Journal, 13(3), 355-373. https://doi.org/10.1108/14635770610668839

Li, S., \& Zuo, X. (2020). Agency Costs in Family Business: A Review. Journal of Service Science and Management, 13(2), 377-387. https://doi.org/10.4236/jssm.2020.132025

Lin, L., \& Lin, D. (2013). Agency Costs of Free Cash Flow and Bidders' Long-run Takeover Performance. Universal Journal of Accounting and Finance, 1(3), 95-102.

Martin-Reyna, J. S., \& Duran-Encalada, J. (2015). Effects of Family Ownership, Debt and Board Composition on Mexican Firms Performance. International Journal of Financial Studies, 3(1), 56-74. https://doi.org/10.3390/ijfs3010056

Martin, G., Gómez-Mejía, L. R., Berrone, P., \& Makri, M. (2017). Conflict between Controlling Family Owners and Minority Shareholders: Much Ado about Nothing? Entrepreneurship Theory and Practice, 41(6), 999-1027. https://doi.org/10.1111/etap.12236

McKinley, W., Latham, S., \& Braun, M. (2014). Organizational Decline and Innovation: Turnarounds and Downward Spirals. Academy of Management Review, 39(1), 88-110. https://doi.org/10.5465/amr.2011.0356

Miller, K. D., \& Bromiley, P. (1990). Strategic Risk and Corporate Performance: An Analysis of Alternative Risk Measures. Academy of Management Journal, 33(4), 756-779. https://doi.org/10.2307/256289

Muriithi, J. (2017). Analysis of the Effect of Operating Costs on Financial Performance of Occupational Pension Schemes in Kenya. Research Journal of Finance and Accounting, 8(1), $40-49$.

Ntoung, A. T. L., Vila Biglieri, J. E., Outman, B. C., Masárová, E., Babounia, A., \& Kome, C. M. (2017). Family Firms and Performance Empirical Analysis from Spain. Corporate Ownership and Control, 14(4), 380-395. https://doi.org/10.22495/cocv14i4c2art4

Olaniran, O., Namusonge, G. . S., \& Muturi, W. (2016). The Role of Risk-taking on Performance of Firms on Nigerian Stock Exchange. International Journal of Research in Business Studies and Management, 3(3), 36-44.

PricewaterhouseCoopers. (2019). Family Business Survey 2018: Indonesia Report. PriceWaterhouseCoopers LLP.

Sageder, M., Mitter, C., \& Feldbauer-Durstmüller, B. (2018). Image and Reputation of Family 
Firms: A Systematic Literature Review of the State of Research. Review of Managerial Science, 12(1), 335-377. https://doi.org/10.1007/s11846-016-0216-x

Saidat, Z., Bani-Khalid, T. O., Al-Haddad, L., \& Marashdeh, Z. (2020). Does Family CEO Enhance Corporate Performance? The Case of Jordan. Economics \& Sociology, 13(2), 4352. https://doi.org/10.14254/2071-789X.2020/13-2/3

Sánchez, M. G., \& de Vega, M. E. M. (2018). Corporate Reputation and Firms' Performance: Evidence from Spain. Corporate Social Responsibility and Environmental Management, 25(6), 1231-1245. https://doi.org/10.1002/csr.1634

Sanjaya, I. P. S. (2016). Impact of Cash Flow Right Leverage of Controlling Shareholder on Performance in Indonesia. Jurnal Akuntansi, XX(3), 363-374.

Setia-Atmaja, L., Tanewski, G. A., \& Skully, M. (2009). The Role of Dividends, Debt and Board Structure in the Governance of Family Controlled Firms. Journal of Business Finance \& Accounting, 36(7-8), 863-898. https://doi.org/10.1111/j.1468-5957.2009.02151.x

Simamora, A. J. (2021). Managerial Ability in Founding-Family Firms: Evidence from Indonesia. International Journal of Productivity and Performance Management, ahead-of-p(ahead-ofprint). https://doi.org/10.1108/IJPPM-07-2020-0388

Singh, M., \& Davidson III, W. N. (2003). Agency Costs, Ownership Structure and Corporate Governance Mechanisms. Journal of Banking \& Finance, 27(5), 793-816. https://doi.org/10.1016/S0378-4266(01)00260-6

Sitthipongpanich, T. (2017). Family Ownership and Free Cash Flow. International Journal of Managerial Finance, 13(2), 133-148. https://doi.org/10.1108/IJMF-06-2014-0088

Staw, B. M., Sandelands, L. E., \& Dutton, J. E. (1981). Threat Rigidity Effects in Organizational Behavior: A Multilevel Analysis. Administrative Science Quarterly, 26(4), 501-524. https://doi.org/10.2307/2392337

Susanto, A. B., Wijanarko, H., Susanto, P., \& Mertosono, S. (2007). The Jakarta Consulting Group on Family Business. The Jakarta Consulting Group.

Tabor, W., Chrisman, J. J., Madison, K., \& Vardaman, J. M. (2018). Nonfamily Members in Family Firms: A Review and Future Research Agenda. Family Business Review, 31(1), 5479. https://doi.org/10.1177/0894486517734683

Tsai, H.-F., \& Luan, C.-J. (2016). What Makes Firms Embrace Risks? A Risk-Taking Capability Perspective. BRQ Business Research Quarterly, 19(3), 219-231. https://doi.org/10.1016/j.brq.2016.01.002

Vieira, E. F. S. (2014). The Effect on the Performance of Listed Family and Non-Family Firms. Managerial Finance, 40(3), 234-253. https://doi.org/10.1108/MF-06-2013-0134

Vieira, E. F. S. (2020). The Earnings Announcements Consequences in Public Family Firms. International Journal of Banking, Accounting and Finance, 11(1), 71. https://doi.org/10.1504/IJBAAF.2020.104484

Warta Ekonomi. (2014). Ini 20 Perusahaan Paling Dikagumi Versi Fortune. WartaEkonomi.Co.Id. https://www.wartaekonomi.co.id/read26863/ini-20-perusahaanpaling-dikagumi-versi-fortune

Warta Ekonomi. (2015). Inilah Pemenang “Indonesia Most Admired Companies 2015." WartaEkonomi.Co.Id. https://www.wartaekonomi.co.id/read53551/inilah-pemenangindonesia-most-admired-companies-2015

Yung, K., \& Chen, C. (2018). Managerial Ability and Firm Risk-Taking Behavior. Review of Quantitative Finance and Accounting, 51(4), 1005-1032. https://oi.org/10.1007/s11156017-0695-0

Zahra, S. A. (2018). Entrepreneurial Risk Taking in Family Firms: The Wellspring of the Regenerative Capability. Family Business Review, 31(2), 216-226. https://doi.org/10.1177/0894486518776871

Zattoni, A., Gnan, L., \& Huse, M. (2015). Does Family Involvement Influence Firm Performance? 
Exploring the Mediating Effects of Board Processes and Tasks. Journal of Management, 41(4), 1214-1243. https://doi.org/10.1177/0149206312463936

Zhang, W., \& Cao, L. (2016). Family Involvement, Internal Control and Agency Costs Evidences from China's listed Family Firms. Perspectives in Science, 7, 45-51. https://doi.org/10.1016/j.pisc.2015.11.009 